\title{
Business Viability of Small Combine Harvester in Haor Areas
}

\author{
AKM Saiful Islam, Md. Ashraful Alam, M. Kamruzzaman, Md. Golam Kibria Bhuiyan, \\ Md. Monirul Islam, and Mohammad Rezoan Bin Hafiz Pranto
}

\section{ABSTRACT}

Haor areas are the most vulnerable areas in Bangladesh. Rice is the major food crops grown in the hoar areas despite natural threats during the harvesting period. The appropriate size of the mechanical harvester is one of the solutions to mitigate the natural calamities and labor shortage in the hoar regions. This paper examines the technical and financial performance of a small combine harvester with the aim of determining its market viability in Bangladesh's hoar areas. Based on the field test and economic assessment, data on field power, forward speed, fuel consumption, time allocation in harvesting, hire fee, and payback period of machine were determined. The study showed that the operation by width was $10 \%$ less than the operation by longitudinal. Plot length and area of the plot should be more than $25 \mathrm{~m}$ and $400 \mathrm{~m} 2$, respectively, to operate the small combine harvester at full capacity. Harvesting speed ranged from $0.63-0.90 \mathrm{~km} \mathrm{hr-1}$, and actual field capacity ranged from $0.03-0.05$ ha $\mathrm{hr}-1$. Fuel consumption ranged from 25$32 \mathrm{~L}$ ha-1 due to slow cutting speed. The plant density was observed higher due to cultivating high yielding variety. The machine should be operated at a low speed, preferably walking speed, to avoid clogging in the conveying chain. The combine harvester has used $56 \%$ of the harvest time, and a remaining $44 \%$ for turning purposes and other inevitable uses. The small combine harvester recorded $\mathbf{1 . 1 2 - 1 . 4 0 \%}$ loss of grain. However, grain damaged was not observed during harvesting. The small combine harvester becomes profitable for the investment cost of $T k 3,50,000$ with a hiring rate of Tk 10,000 Tk ha-1 following 15 ha of harvesting area in a harvest capability of 0.04 ha hr-1. This machine is suitable for a small size of land where larger sizes of machines are inaccessible. This would offer small entrepreneur different choices of paddy harvesting mechanization to encourage future adoption of enhanced innovations.

Keywords: Entrepreneur, harvesting speed, field capacity, hiring charge.
Submitted : April 25, 2021

Published : May 17, 2021

ISSN: $2684-1827$

DOI: 10.24018 /ejfood.2021.3.3.290

\section{AKM Saiful Islam}

Principal Scientific Officer

Farm Machinery and Post-Harvest Technology Division, Bangladesh Rice Research Institute, Gazipur, Bangladesh.

(e-mail: akmsaifulislam68@gmail.com) Md. Ashraful Alam*

Senior Scientific Officer

Farm Machinery and Post-Harvest Technology Division, Bangladesh Rice Research Institute, Gazipur, Bangladesh.

(e-mail: ashraf1982s ${ }^{\circledR}$ gmail.com)

M. Kamruzzaman

Senior Scientific Officer

Farm Machinery and Post-Harvest Technology Division, Bangladesh Rice Research Institute, Gazipur, Bangladesh.

(e-mail: milonbrri@gmail.com)

Md. Golam Kibria Bhuiyan

Senior Scientific Officer

Farm Machinery and Post-Harvest Technology Division, Bangladesh Rice Research Institute, Gazipur, Bangladesh.

(e-mail: kibria_1971@yahoo.com)

Md. Monirul Islam

Scientific Officer

Farm Machinery and Post-Harvest Technology Division, Bangladesh Rice Research Institute, Gazipur, Bangladesh.

(e-mail: monir.ae.bau@gmail.com)

Mohammad Rezoan Bin Hafiz Pranto

Scientific Officer

Irrigation and Water Management

Division, Bangladesh Rice Research

Institute, Gazipur, Bangladesh.

(e-mail: pranto.brri@gmail.com)

*Corresponding Author

\section{INTRODUCTION}

Rice is the primary food item of Bangladeshi people. Its production is a significant activity in the fight against food poverty and the establishment of self-sufficiency for both local consumption and trade. Farmer faces a severe problem in harvesting rice crops due to a lack of farm labor and natural calamities. Harvesting operation is still a labor-intensive operation in Bangladesh. Hand sickle harvesting accounts for more than $90 \%$ of rice production and threshed by thresher or power tiller cleaning by traditional method. Due to a labor shortage and a high wage rate, farmers face significant challenges in harvesting paddy on time. Farmers depended on the migrated labor to complete the harvesting operation. A field survey report showed that a combine harvester takes one day to harvest one hectare of rice land, whereas in the haor areas, seven people are expected to harvest the same area in 
three days [23]. Rice harvesting by hand is a time-consuming, expensive, and labor-intensive process that takes around 100150 people an hour to harvest one hectare of paddy field [27]. Paddy harvesting with a combine harvester needed $34 \%$ more labor than manual harvesting [25]. According to [3], the combine harvester is an efficient, energy-effective, laborsaving, and time-saving machine, but its initial cost is very high. A high-tech combine harvester is needed to deliver high productivity with minimal crop losses, damage, and machine maintenance and repair costs [20], [26].

Many factors influence the effective operation of a combine harvester, including land size, machine accessibility, field to field distance, crop characteristics, weather, and soil type, combine harvester readiness and management, and economic factors [2], [18]. The type and size of equipment used has an effect on the crop's harvested yield, nutritive value, and production costs [9]. In Maisharkandi, Mithamain upazilla, Kishorganj district, [3] investigated land sizes. The author discovered that $8 \%$ of the lands measured less than $750 \mathrm{~m}^{2}$ in scale. According to [4], the area covered by harvesting operations was determined by the size and shape of the field. The main requirements for crop harvesting include optimal agronomic conditions while ensuring minimum loss of products and appropriate quality of grain [12], [31].

The costs of machinery are divided into fixed and variable costs, which add up to the overall machine cost [10], [21], [29]. According to [19], a combine harvester should be run at the lowest possible cost thus achieving maximum efficiency. Several studies have calculated harvesting costs using possible ways and measurement procedures for a number of harvesting methods [3], [15]-[18], [22]. Due to the importance of timeliness in agricultural and rice production, securing working conditions and optimal efficiency of combine harvesters is important. The ability to use a combine harvester is limited, as it is only available for a few weeks or months each year. As a result, some work must be undertaken to justify the purchase of a combine harvester. Machinery selection and proper planning to operate the machine ensured the profitability of the service business. In contrast to current manual harvesting methods, the combine harvester must be evaluated under a variety of field and crop conditions. As a result, the current research was conducted to assess field response (field capacity, field efficiency), time distribution in performing harvesting operation in different farm sizes, and distribution of cost in harvesting operation. This study emphases on the business viability of combine harvesters for farmers and entrepreneur which will be helpful for policy makers, extension workers and related user. This study emphases on the business viability of combine harvesters for farmers and entrepreneur which will be helpful for policy makers, extension workers and related user.

\section{METHODOLOGY}

\section{A. Experimental Location and Period}

During boro 2020, this research was carried out in Maisherkandi, Mithamain upazila, Kishorganj district. The crop test conditions (variety, crop duration), crop spacing (row and hill), plant height, and crop density (plants $\mathrm{m}^{-2}$ ) were measured from $0.5 \mathrm{~m}^{2}$ areas in three different locations in each region. The small combine harvester was used to harvest the high yielding rice variety BRRI dhan29. Harvester machines harvested crops from 16 March to 10 May 2020. The technical specification of small combine harvesters is given in Table I.

TABLE I: TECHNICAL SPECIFICATIONS OF THE COMBINE HARVESTER

\begin{tabular}{cc}
\hline Parameters & \\
Name & Small combine \\
Country of origin & China \\
Price, Tk. & $3,50,000$ \\
Max power, kW & 8 \\
Rated speed, rpm & 3000 \\
Tracking tire & Full track \\
Fuel type & Diesel \\
Fuel tank capacity, $\mathrm{L}$ & 5 \\
Bagging facility & Yes \\
Working width, $\mathrm{m}$ & 1.0 \\
\hline
\end{tabular}

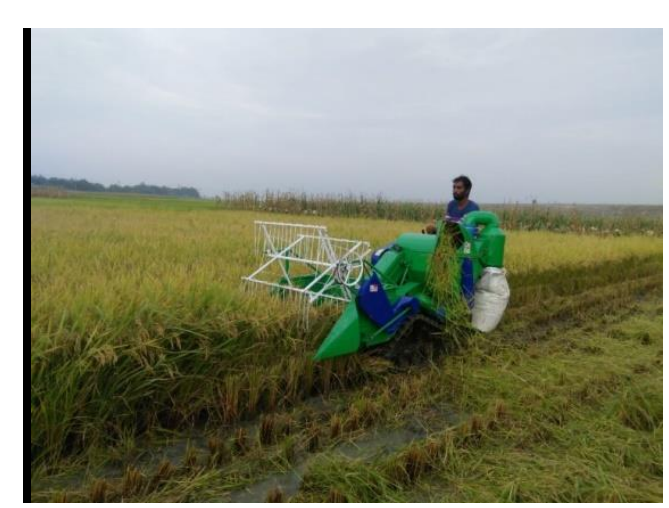

Fig. 1. Field operation of small combine harvester.

\section{B. Field Performances}

Operating speed, real field strength, field efficiency, work hour, and fuel consumption are all factors to consider when evaluating field performance (Fig. 1). The ratio of the total harvested area divided by the total time of operation is known as effective field capacity. The ratio between the harvester's productivity under actual operating conditions and the theoretical maximum possible productivity is known as land efficiency. After the harvesting process, the fuel consumption was determined by filling the fuel tank with a measuring cylinder. The effective time (time spent conducting the actual harvesting operation), turning time (time spent by combine harvesters turning and reversing without cutting the plant), and other time parameters were used (the operator takes time in resting and setting or maintaining the machine). The forward operating speed was calculated by recording the time it took to harvest each row and measuring the distance from the row with a stopwatch and a measuring tape. By adding the speeds of all the rows and dividing by the number of rows, the average operating speed was determined. Daily harvesting area coverage, travel distance $(\mathrm{km})$ from machine shed to field, and machinery trouble were all collected via direct monitoring. Grain that appeared in the $1 \mathrm{~m}^{2}$ was collected in three places in each field before and after harvesting. The grain's moisture and weight were calculated as a percentage of total yields in a unit area. The length and 
width of the plot (in m) were measured with plastic tape and meticulously recorded.

\section{Operation Principle}

The major parts of small combine harvester were the engine, crawler, transmission gear, front header, thresher, cleaner, grain tank, delivery chute, etc. Reel shifted the stems, and stems were guided into the header platform. The cutter bar cut the stems and separated from the root. There are two sets of cutting blades, and the stem is cut in two stages. By conveying the chain, the stems were compressed and fed into the threshing cylinder. The threshing drum, which shakes the grains loose from their stalks, shakes the panicle. The grains are sieved and fall into a storage tank below. The cyclone separator washed the grain and gathered it directly into the jar. The unnecessary material (chaff and stalks) is transported to the back of the system on straw walkers, which are conveyors. Straw is delivered in the back section after threshing. With the reel speed and cutter bar speed, the forward motion of the combine harvester should be optimized.

\section{Economic Analysis}

The following equation was used to measure the combine harvester's operating costs.

$\mathrm{AC}=\mathrm{FC}+\mathrm{VC}$

where

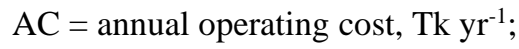

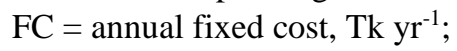

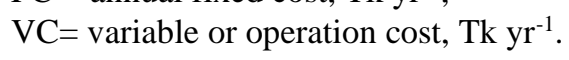

1. Fixed cost $(F C)$

It is measured using the capital consumption (CC) method and is independent of machine use. The cumulative depreciation and interest change is combined into a sequence of equivalent annual compound interest payments using a capital recovery factor (CRF) [11].

$\mathrm{CC}=(\mathrm{P}-\mathrm{S}) \mathrm{CRF}+\mathrm{S} \times \mathrm{i}$

$\mathrm{CRF}=\frac{i(i+1)^{n}}{(1+i)^{n}-1}$

where

$\mathrm{CC}$ = capital consumption;

$\mathrm{P}=$ purchase price of the combine harvester, Tk;

$\mathrm{S}=$ salvage value, $\mathrm{Tk}$;

$\mathrm{CRF}=$ capital recovery factor;

$\mathrm{i}=$ interest on investment, $\%$;

$\mathrm{n}=$ life of machine, $\mathrm{yr}$.

2. Variable cost $(V C)$

These expenditures are related to the harvester's usage and are determined using the equation below [11].

$$
V C=\frac{A}{C}[(R \& M) \times P+L]
$$

$\mathrm{R} \& \mathrm{M}=$ repair and maintenance cost, $\%$

$\mathrm{L}=$ labor cost, $\mathrm{Tk} \mathrm{hr}^{-1}$.

\section{E. Rental Charge Calculation}

The price of the machine, the cost of fuel, the cost of labor, the cost of transportation, the annual use, and the benefit decide the cost of renting a unit ( 1 ha) of land. Based on the assumption, the rental charge for a combine harvester was determined. Tk 3,50,000 purchase price, 12 percent interest on investment, $5 \%$ repair and maintenance cost, 8 -year useful life, fuel price Tk $70 \mathrm{~L}^{-1}$, operator charge Tk $900 \mathrm{day}^{-1}$, and manual harvesting and threshing cost Tk 16,500 ha-1.

\section{F. Break-even Analysis}

The break-even point (BEP) is the point at which no gain or loss is realized. The BEP of the machine was determined using the formula below.

$$
B E P=\frac{F C}{C R-V C}
$$

where

$\mathrm{BEP}=$ break-even point, ha $\mathrm{yr}^{-1}$;

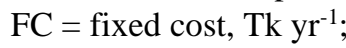

$\mathrm{VC}=$ variable cost, $\mathrm{Tk} \mathrm{ha}^{-1}$

$\mathrm{CR}=$ custom hire rate, $\mathrm{Tk} \mathrm{ha}^{-1}$.

\section{G. Farmers' Preference}

Farmers were asked on the performance of combine harvester through open-ended questionnaires. The comments were validated, summarized, and presented in tabular form.

\section{H. Data Analysis}

MS-Excel 2013 was used to analyze the data, which was then displayed in tabular and graphical form.

\section{RESULTS \\ A. Relationship between Forwarding Speed and Plot Length in the Haor Areas}

Combine harvester circularly harvested the crop. As a result of the rotational movement, the cutting length of the rice field subsequently decreased. The combine harvester's forward speed was calculated using the motion at a longitudinal and wide angle. Combine harvester forward speed depended on plot length. The forward speed of the combine harvester drops with the plot length decreases (Fig. 2 ). As the width is smaller than the length, the forward speed decreased substantially (Fig. 3). Fig. 2 and 3 indicated that $10 \%$ speed reduction occurred in widthwise compared to lengthwise operation.

where

$\mathrm{A}=$ annual area coverage, ha;

$\mathrm{C}=$ effective field capacity of the harvester, ha $\mathrm{hr}^{-1}$; 


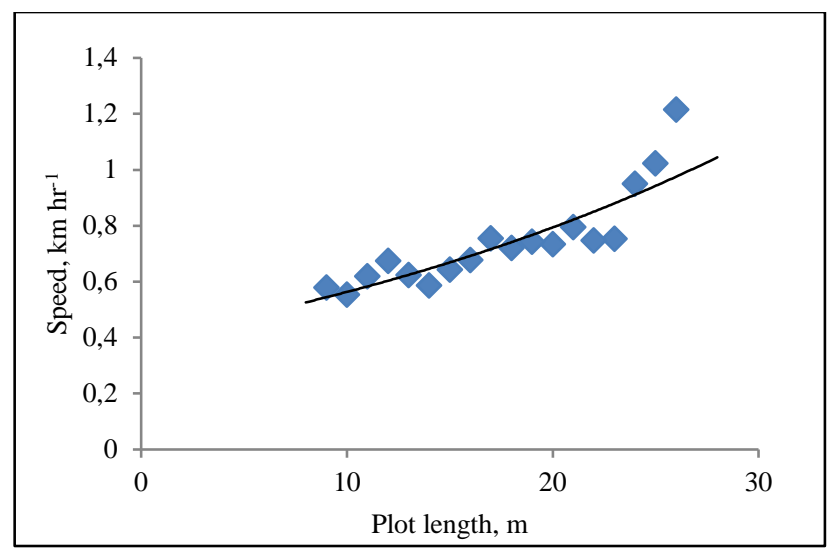

Fig. 2. Forward speed of combine harvester in lengthwise operation.

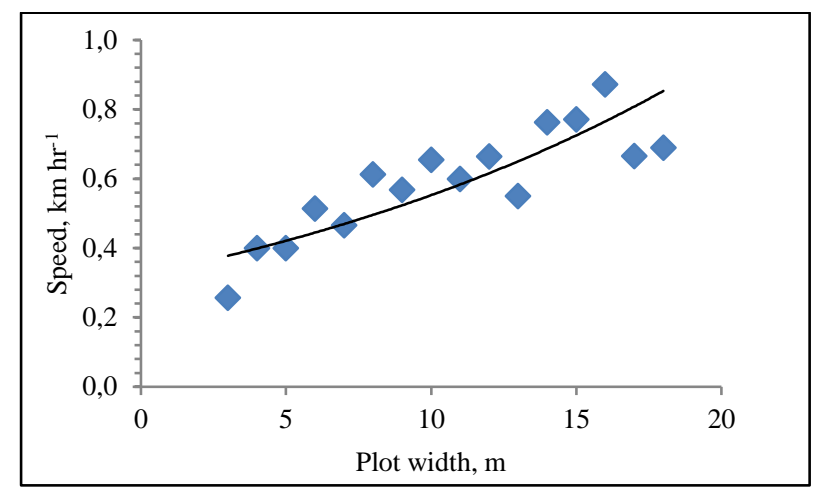

Fig. 3. Forward speed of combine harvester in widthwise operation.

\section{B. Turning Events}

Fig. 4 shows that with the lengthening of the plot, the turning event became less frequent. A result of turning events is turning failure. The number of turning events increased when the plot length was less than $25 \mathrm{~m}$. Therefore, small combine harvester should be operated in a plot length of more than $25 \mathrm{~m}$ to reduce turning events.

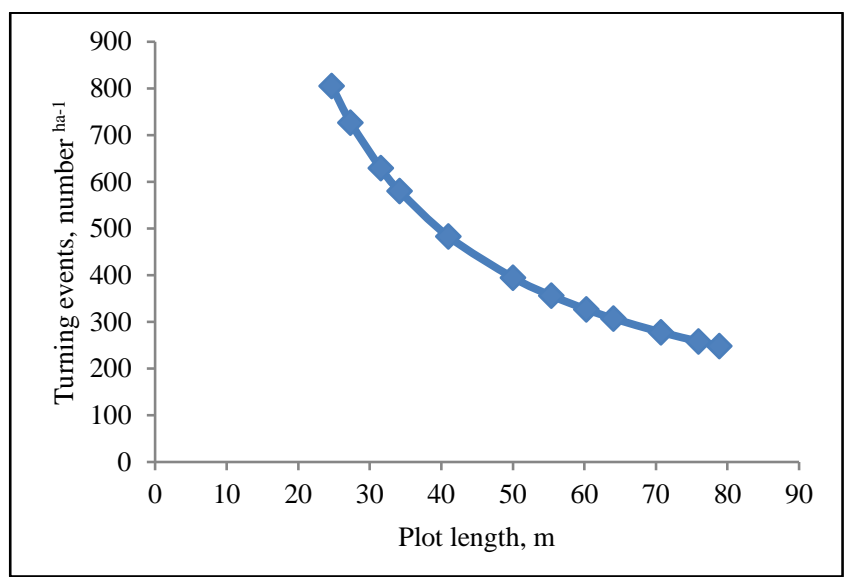

Fig. 4. Turning events of the small combine harvester.

\section{Time Loss in Turning}

Fig. 5 shows that time loss in turning decreases with the increase in plot size. Smaller sizes of plot required more turning events, ultimately increase the time loss in turning. Plot areas less than $400 \mathrm{~m}^{2}$ mostly affected the turning events of small combine harvester having a cutting width of $1.0 \mathrm{~m}$.

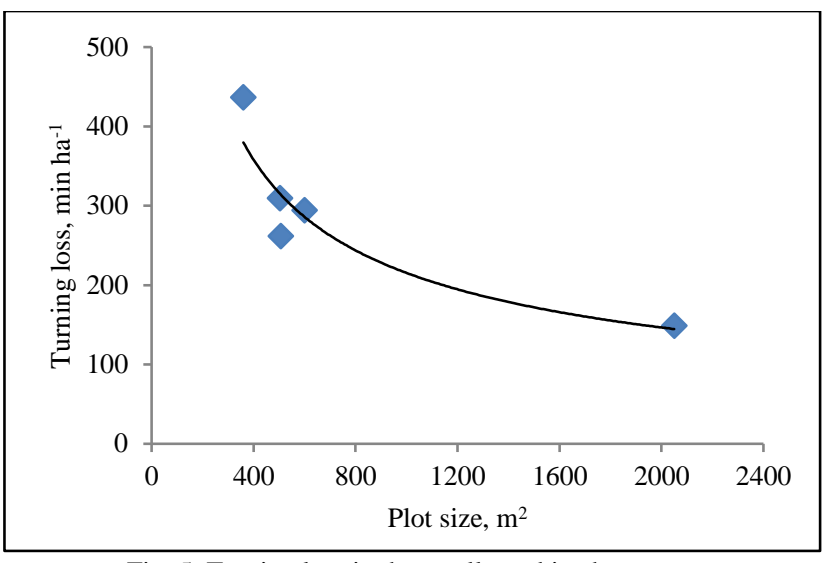

Fig. 5. Turning loss in the small combine harvester.

\section{Harvesting Capacity to Combine Harvester Concerning the Land Size}

The harvesting capability of the combine harvester was determined by the size of the land. Fig. 6 depict a small combine harvester's field capacity in relation to the size of the land. The harvesting capacity to combine harvester increased with an increase in land size. Combine harvester worked at full capacity for the larger sizes of land due to less turning events. The size of the land should be at least $400 \mathrm{~m}^{2}$ to operate the small combine harvester having a cutting width of $1 \mathrm{~m}$ at full capacity. The crop field should be selected based on the size of the land to get the highest field performance of combine harvester.

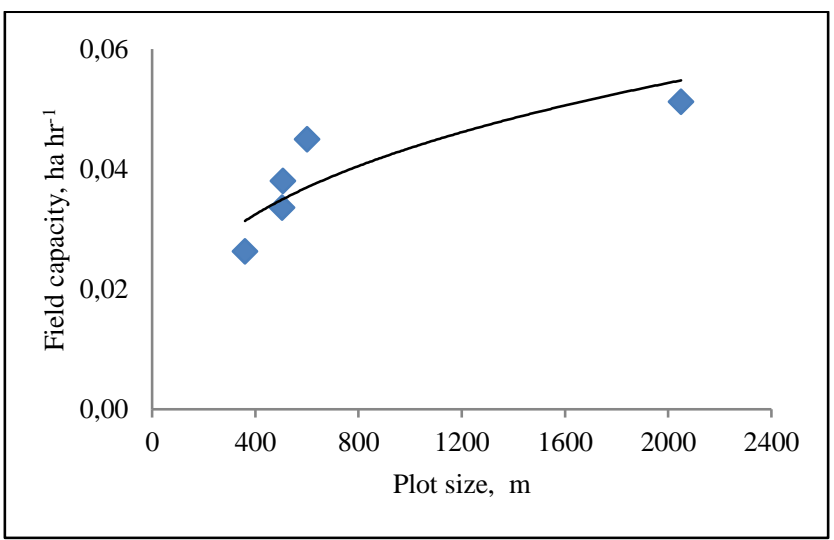

Fig. 6. Field capacity of a combine harvester concerning the land size.

\section{E. Field Efficiency}

Fig. 7 shows the field efficiency of a small combine harvester to land size. The efficiency of a combine harvester in the field varied depending on the size of the land. The highest field efficiency was observed for the land sizes of more than $2000 \mathrm{~m}^{-2}$, however the lowest in $400 \mathrm{~m}^{-2}$. Hence, field sizes of $400 \mathrm{~m}^{2}$ should be avoided for the small combine harvester. 


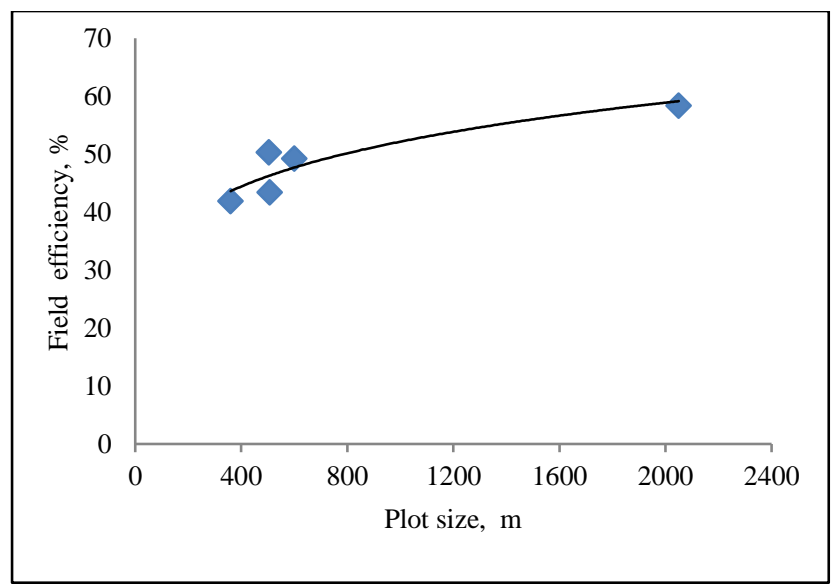

Fig. 7. Field efficiency of a combine harvester for land size.

\section{F. The Average Field Capacity of Small Combine Harvesters in the Haor Area}

A small combine harvester harvested the 10 farmers' rice field. Table II shows the field capacity and field efficiency of the combine harvester. The operating speed of the combine harvester was observed $0.63-0.90 \mathrm{~km} \mathrm{hr}^{-1}$. The actual field capacity of the small combine harvester was 0.03-0.05 ha hr-1. Because of the low engine horsepower, the operating speed of a small combine harvester was observed to be low in haor areas.

\begin{tabular}{|c|c|}
\hline Parameter & Value \\
\hline Speed, $\mathrm{km} \mathrm{hr}^{-1}$ & $0.79 \pm 0.11$ \\
\hline Theoretical field capacity, ha $\mathrm{hr}^{-1}$ & $0.08 \pm 0.01$ \\
\hline Actual field capacity, ha hr-1 & $0.04 \pm 0.01$ \\
\hline Field efficiency, $\%$ & $49 \pm 6.12$ \\
\hline
\end{tabular}

\section{G. Time Distribution in Combine Harvester Operation}

The distribution of time in small combine harvester operation was shown in Fig. 8. The distribution of time included harvesting, turning, and other time. Harvesting time showed the highest $(56.0 \%)$ than at other times in haor areas. Turning time accounted for $16 \%$ of the total time spent with the combine harvester. The remaining $28 \%$ of the total harvesting operation time was spent on repairs, idle time, and rain-related work stops.

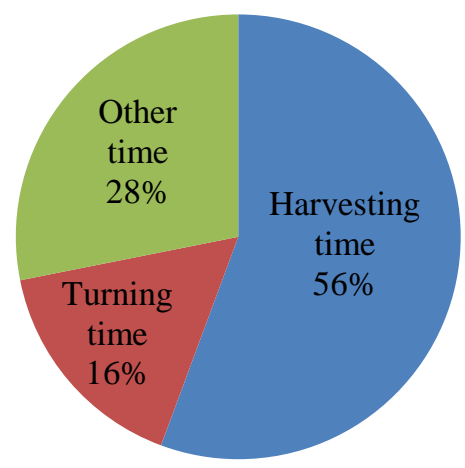

Fig. 8. Time distribution in combine harvester operation.

\section{H. Fuel Consumption}

In six days, a harvester worked in ten rice fields. The amount of fuel consumed was determined by the area covered, the distance from the shed to the rice field, and the movement from plot to plot [3]. The total fuel required to harvest 0.39 hectares of land was estimated to be 30 liters, or $32 \mathrm{~L} \mathrm{ha}^{-1}$. Plots in haor areas were far from the machinery shed, needing additional machine fuel. The harvester traveled an average of 0.67 kilometers per day from the machinery shed to the plot.

\section{Daily Area Coverage}

Fig. 9 shows the regular area coverage of a combine harvester. Depending on field availability and plot to plot size, daily harvesting areas ranged from 0.04 to 0.26 ha. In the haor regions, small plot sizes are scarce. With careful plot selection, area coverage increases. Harvesting of nearby plots, known as operational consolidation, improves daily area coverage. After harvesting in haor areas is completed, the machine can be moved to other non-haor areas to expand annual coverage.

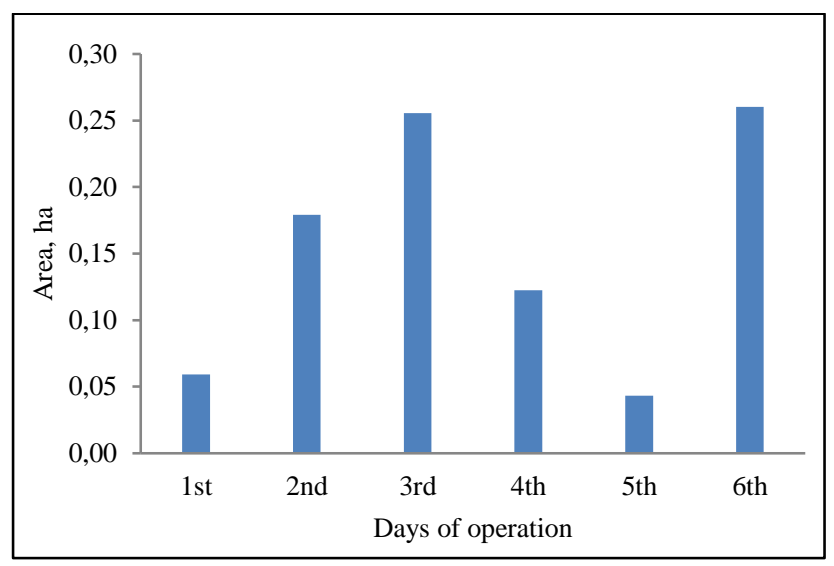

Fig. 9. Daily area coverage by the small combine harvester.

\section{J. Field Capacity}

Because of the reduced turning loss, field capacity improved as plot size increased [1]. The capability of the field differs based on the field conditions (i.e., land shape, size, operator skill, crop condition, etc.). Based on field observations, field capacity values were plotted. Depending on the availability of smaller plot sizes and plot to plot width, field potential ranged from 0.03-0.09 ha hr-1 (Fig. 10). The actual field potential of a combine harvester was found to be $0.06 \mathrm{ha} \mathrm{hr}^{-1}$ on average.

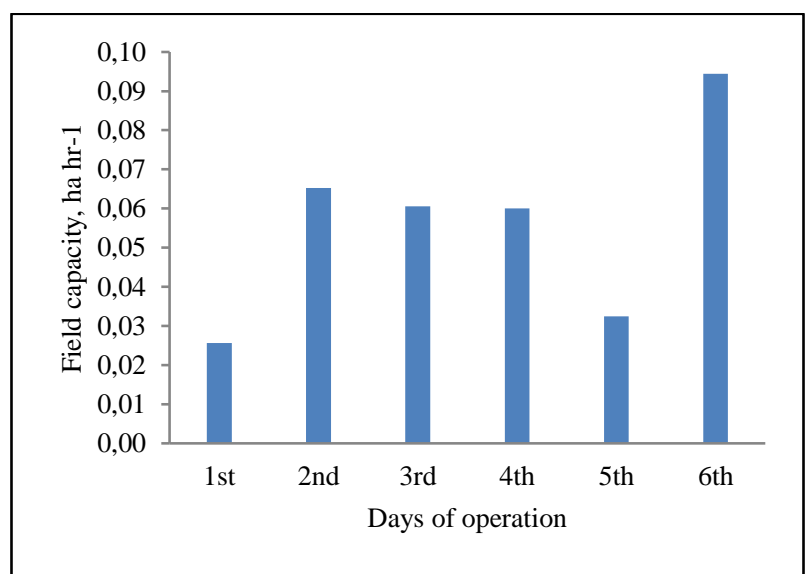

Fig. 10. Daily field capacity of the combine harvester. 


\section{K. Operation Cost}

Variable cost, i.e., operation cost, was categorized as an operator's charge, fuel, and repair cost (Fig. 11). Fuel cost represented the highest (49\%), followed by the operator's charge $(41 \%)$. Repairing cost was observed at a minimum level.

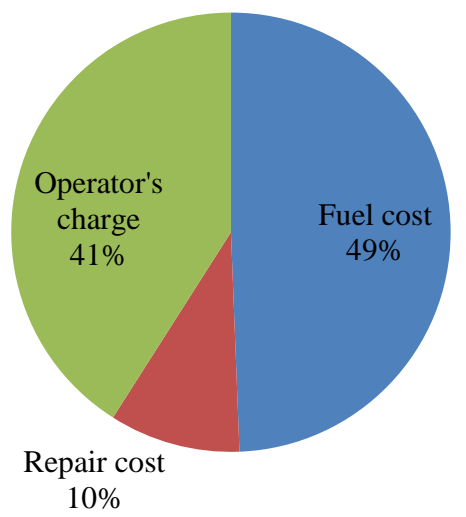

Fig. 11. Cost distribution in the operation of the small combine harvester.

\section{Break-even Area}

\section{Entrepreneurs' point of view}

Based on valid assumptions, Fig. 12 depicts the cost of mechanized harvesting with a small combine harvester and manual harvesting. Mechanized harvesting provided a cumulative annual fixed cost of Tk 85,110 for a Tk 3,50,000 investment. The conventional process, on the other hand, needed 16,500 $\mathrm{Tk} \mathrm{ha}^{-1}$ for the same operation [23]. For a rental fee of Tk 10,000, the break-even area will be 15 ha. Harvesting with a sickle, carrying paddy head or shoulder, threshing with a near drum thresher, and winnowing with a conventional winnower are all part of the traditional process.

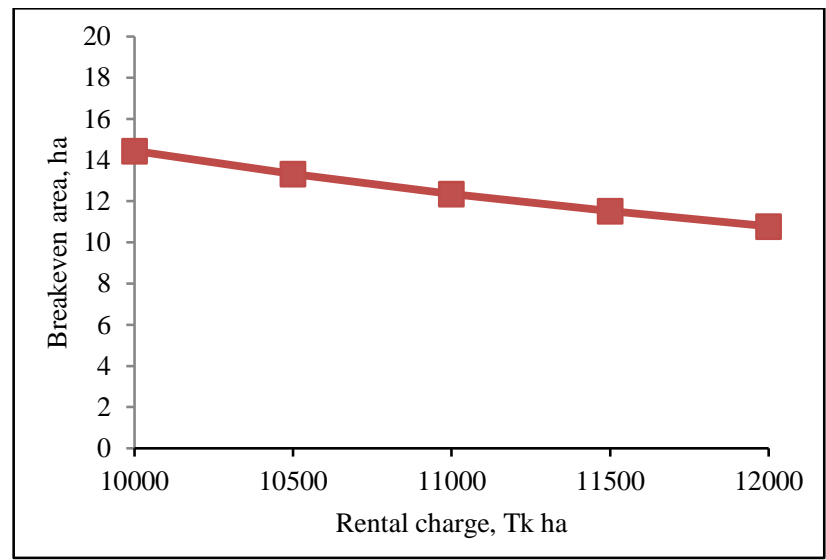

Fig. 12. Break even area for rental charge.

Fig. 13 illustrates the break-even chart for mechanized methods using the small combine harvester. As mentioned earlier, from the entrepreneurs' point of view, the break-even area would be 7 ha for the rental charge of Tk 10,000. Whereas from the farmers' point of view, the break-even area of mechanized harvesting using a small combine harvester would be 8 hectares of rice land.

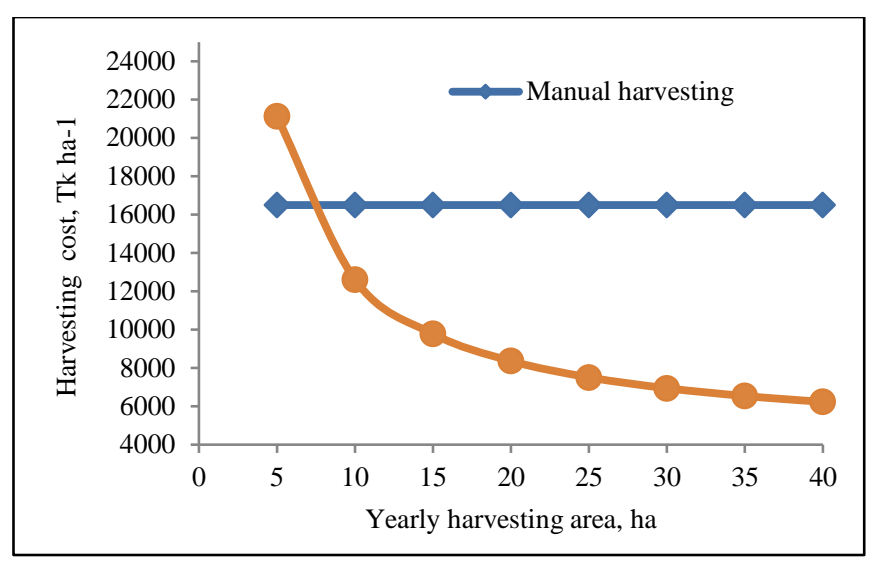

Fig. 13. Break even area for area coverage.

\section{Payback Period}

Fig. 14 depicted the combine harvester's return and payback period from the perspective of the business owner. The profitability of a combine harvester rental service differed depending on the region covered and the rental charge. Benefit levels ranging from 10,000 to $12,000 \mathrm{Tk} \mathrm{ha}^{-1}$ were plotted on graphs. After a yearly harvesting area coverage of 9 ha and a rental fee of $10,000 \mathrm{Tk} \mathrm{ha}{ }^{-1}$, profitability began. If the annual area coverage is estimated to be 20 ha, the payback period for the same rental fee will be 3.0 years. When the region covered expands, so does the profit margin. Under the annual area coverage of 15 ha for the same rental fee, the company would not be viable. The entrepreneurs can see a fast return on their investment if offered a rental charge $10,000 \mathrm{Tk} \mathrm{ha}^{-1}$ for the annual area's coverage of 25 ha in three rice seasons.

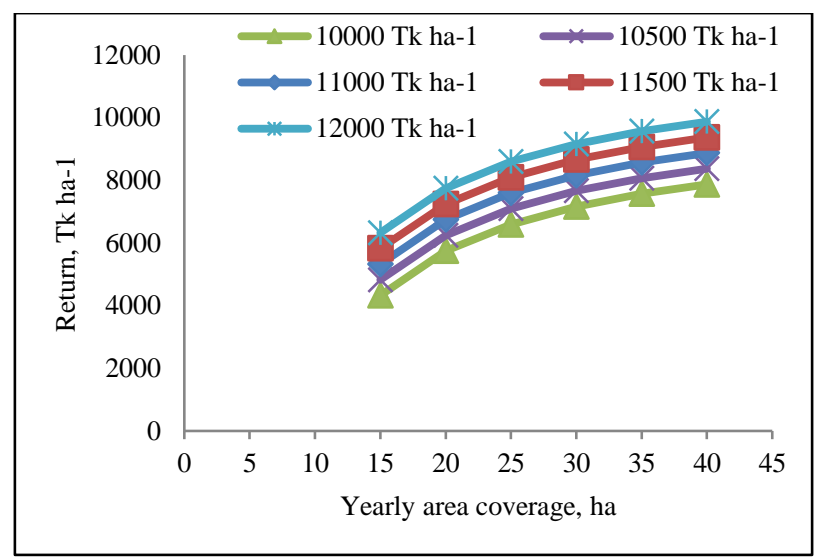

(a)

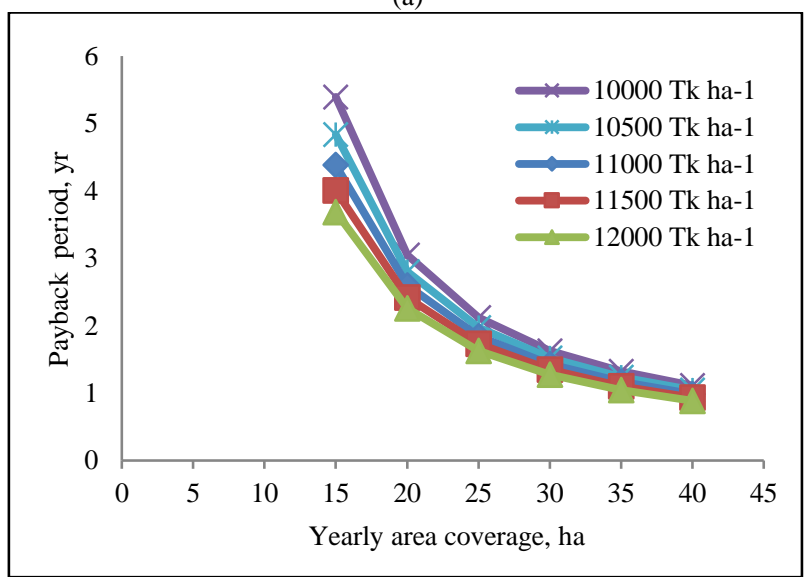

(b)

Fig. 14. Return (a) and payback period (b) of the combine harvester. 


\section{N. Operators' Experience}

The skill of the operator is very important to run the combine harvester efficiently. The machine should be run slowly, i.e., at walking speed. The combine harvester should be calibrated according to the crop nature and variety, moisture content (soft or dry), harvest time, area, crop density, and crop conditions (lodged/unlodged), among other factors. Improper adjustments cause damage to grains or machine. The operator has to take an instant decision on the adjustment of different parts. The system should be run in a lengthwise direction to minimize turning events. The adjacent field should be chosen to reduce the plot-to-plot movement time. We specifically forbid a sudden turn.

\section{O. Machine Status during Operation}

The mechanical fault of the combine harvester during harvesting operation was summarized and presented in Table III.

TABLE III: MACHINE STATUS DURING OPERATION

\begin{tabular}{ll}
\hline \multicolumn{1}{c}{ Parameters } & \multicolumn{1}{c}{ Comments } \\
\hline Header unit & Reel successfully gathered the crop. \\
Two sets of cutter bars are attached in the \\
harvester and cut the crop in the upper and \\
lower portion of the rice plants. The Cutter \\
bar moves smoothly and successfully cut \\
the crop. Can't find the crop uncut. Only \\
panicle feed into the threshing unit \\
Cut crop conveyed to the threshing drum \\
by conveyer belt. Careful movement of the \\
harvester is needed. Overfeeding clogged \\
the conveying unit \\
Grains were separated from panicle \\
successfully \\
Threshing unit & $\begin{array}{l}\text { A cyclone separator cleaned grains. The } \\
\text { cleaning was good. }\end{array}$ \\
Gleaning unit & $\begin{array}{l}\text { Grains were delivered directly to the bag. } \\
\text { The gear mechanism is not the operator's } \\
\text { friendly }\end{array}$ \\
\hline
\end{tabular}

\section{P. Operators' comments}

Operators were asked to make comments on the following issues. The comments are summarized and given in Table IV.

TABLE IV: OPERATORS' COMMENTS ON THE PERFORMANCE OF COMBINE HARVESTER

\begin{tabular}{|c|c|}
\hline \multicolumn{2}{|r|}{ HARVESTER } \\
\hline Parameters & Comments \\
\hline Operation & $\begin{array}{l}\text { Operators did not feel comfortable operating } \\
\text { the harvester due to vibration and noise. } \\
\text { Seating arrangement helped the operator ease } \\
\text { of operation }\end{array}$ \\
\hline Straight movement & Faced no problem in a straight movement \\
\hline Plot to plot movement & $\begin{array}{l}\text { Operators faced no difficulty with transferring } \\
\text { machine in one plot to another due to smaller } \\
\text { in size }\end{array}$ \\
\hline $\begin{array}{l}\text { Lowering and } \\
\text { uplifting in the field }\end{array}$ & $\begin{array}{l}\text { There is no problem in uplifting on harvester } \\
\text { from plot to the road due to smaller in size }\end{array}$ \\
\hline Driving on the road & $\begin{array}{l}\text { There is no difficulty in moving on the road. } \\
\text { However, turning in the road caused crawler } \\
\text { damage. }\end{array}$ \\
\hline
\end{tabular}

\section{Q. Farmers' Comments}

Farmers were asked to express comments on the following issues. The comments are summarized and given in Table V.
TABLE V: FARMERS' COMMENTS ON THE PERFORMANCE OF COMBINE HARVESTER

\begin{tabular}{ll}
\hline \multicolumn{1}{c}{ Parameters } & \multicolumn{1}{c}{ Comments } \\
\hline Grain cleaning & $\begin{array}{l}\text { More than 95\% of cleaned grain was obtained. } \\
\text { Every farmer satisfied the grain cleaning }\end{array}$ \\
Farmers did not find any significant amount of \\
grain damage
\end{tabular}

\section{DISCUSSION}

Mechanized cultivation is changing the face of the agricultural production system through the combined effort of government and non-government organizations for sustainable food security in the country. The demand of modern agricultural machinery is increasing day by day, especially rice transplanter and combine harvester. Combine harvester with different models are available in Bangladesh. The limitation of farm road, land size, crop condition and farmers choice are the important factors in the adoption of combine harvester. A business viable combine harvester could be a good scope of income generation for small entrepreneurs or farmers in the rural area of Bangladesh.

The experimental findings show that the field efficiency of the combine harvester was strongly influenced by the forward speed of the combine harvester (Fig. 2 and Fig. 3). A study recommended that farm machinery should be operated in lengthwise to reduce the turning events. For the small size of the plot, the widthwise operation drastically reduced the forward speed of combine harvester [1]. The minimization of time loss in turning is another factor to maximize the harvesting capacity of combine harvester (Fig. 4 and Fig. 5). In this regard, the plot length should be selected for 25 and $30 \mathrm{~m}$ for the Sifang and Zoomlion brand combine harvester in haor areas. The minimum sizes of plots should be more than $500 \mathrm{~m}^{2}$ and $800 \mathrm{~m}^{2}$ for Sifang (cutting width $1.5 \mathrm{~m}$ ) and Zoomlion model combine harvester, respectively, to operate at full capacity. [3], [24], [30].

The field performance of combine harvester varied with the operating speed, cutting width of machine, turning events, field size and shape etc. The operating speed of combine harvester was observed lower than the recommended operating speed of ASABE standard (Table II). The conventional and mid-size combine operating speeds were within the ASABE recommended operating speed range of 3-6.5 $\mathrm{km} \mathrm{hr}^{-1}$ for harvesting with a self-propelled combine [8]. The operating speed of Sifang and Zoomlion combine harvester was observed 1.40-1.90 and 1.23-3.20 in haor areas [3], [24]. The theoretical and actual field capacity of small combine harvester observed low compared to the other models. It was due to low engine horsepower and cutting width. The performance of the harvester machine is not 
desirable for larger sizes of land in the haor areas. Because the harvesting season is very short, on the other hand, farmers have to harvest crops within very short to avoid natural calamities. The harvesting capacity of the small combine harvester is relatively low. However, the advantage of the small size combine harvester is to work well in smaller sizes of fields. In haor areas, [24] found that the Sifang model whole feed combine harvester's theoretical and effective field capacities were 0.12 and $0.09 \mathrm{ha} \mathrm{h}^{-1}$, respectively. The theoretical and effective field capacities of full feed and half feed combines, according to [27], were 0.495 and 0.361 ha $\mathrm{hr}^{-1}$, respectively. Among all the operations studied by [5], paddy harvesting had the longest field time $(1.54 \mathrm{~h})$ and the smallest field capacity $\left(0.67 \mathrm{ha} \mathrm{hr}^{-1}\right)$.

The distribution of time in harvesting operation moves the machine to make it economically viable or not. Harvesting cost and harvesting efficiency varied with the time distribution combine harvester. The experimental findings show higher value of harvesting time $(56.0 \%)$ compared to Sifang (45\%) and Zoomlion (48\%) model harvesters, respectively, [3], [24]. According to [31], the Sifang model harvester spent 37 percent (or $1.36 \mathrm{~h} \mathrm{ha}^{-1}$ ) of the total harvesting operation time on actual harvesting, while the remaining 13 percent was spent on cornering, reversing, and dumping time. [5] reported that actual harvesting activities accounted for $66 \%\left(1 \mathrm{hr} \mathrm{ha}^{-1}\right)$ of total harvesting time, while turning and reverse time accounted for $13 \%$ of total harvesting time when using a conventional combine. Harvester machine turning time is a loss factor operation that requires careful planning to avoid slowing down or using extra motion to line up the next row. Some nonproductive activities (such as turning time and adjustment time) are unavoidable; the goal is to reduce the sum of these nonproductive activities, which can account for up to $40 \%$ of total time [11]. With advanced planning and management, most lost-time factors can be reduced.

\section{CONCLUSION}

Machines performed better in small rice fields, according to the findings. Farmers recommended this small combine harvester in small sizes of lands where bigger sizes are inaccessible. The study identifies an opportunity to improve the livelihood of smallholder farmers in haor areas by offering a custom hire service for a small combine harvester. Smallholder farmers may own this machine due to less investment and operate commercially.

\section{ACKNOWLEDGMENT}

The author acknowledges the funding support of "Strengthening Farm Machinery Research Activity for Mechanized Rice Cultivation project, Bangladesh Rice Research Institute, Gazipur, Bangladesh.

\section{CONFLICTS OF INTEREST}

The authors declare that they have no conflict of interest.

\section{REFERENCES}

[1] A. K. M. S. Islam, "Rice mechanization in Bangladesh", Bangladesh Rice Research Institute, Gazipur, Bangladesh, Publication number 260, 2018.

[2] A. K. M. S. Islam, M. A. Rahman, A. K. M. L. Rahman, M. T. Islam, and M. I. Rahman, "Techno-economic performance of 4-row selfpropelled mechanical rice transplanter at farmers' field in Bangladesh", Progressive Agriculture, vol. 27, pp. 369-382, 2016.

[3] A. K. M. S. Islam, M. G. K. Bhuiyan, M. Kamruzzaman, M. A. Alam, and M. A. Rahman, "Custom hire service business of rice combine harvester in haor basin of Bangladesh"., Bangladesh Rice J, vol. 23, pp. 65-75, 2019.

[4] A. K. M. S. Islam, M. T. Islam, M. A. Rabbani, M. A. Rahman, and A. B. M. Z. Rahman, "Commercial mechanical rice transplanting under public private partnership in Bangladesh", Journal of Bioscience and Agriculture Research, vol. 06, pp. 501-511, 2015.

[5] A. Muazu, A. Yahya, W. I. W. Ishak, and S. Khairunniza-Bejo, "Machinery utilization and production cost of wetland, direct seeding paddy cultivation in Malaysia", Agric Agric Sci Procedia, vol. 2, pp. 361-369, 2014.

[6] A. R. Tahir, H. K. Faizan, and K. Ejaz, "Techno-economic feasibility of combine harvester (Class Denominator)-A Case Study", International Journal of Agriculture and Biology, vol. 5, pp. 57-60, 2003.

[7] A. W. Anderson, "Factors affecting machinery costs in grain production", American Society of Agricultural Engineers, Paper No. 88-1057, 1988.

[8] ASAE Standards, "agricultural machinery management data", ASAE D497.4 Science, 85 (2210), 350e357, 2009.

[9] C. A. Rotz, G. W. Roth, K. J. Soder, and R. R. Schnabel, "Economic and Environmental Implications of Soybean Production and Use on Pennsylvania Dairy Farms", Agronomy Journal, vol. 93, pp. 418-428, 2001.

[10] D. Hunt, "Farm Power and Machinery Management", 10th edition, Iowa State University Press, Ames, Iowa, USA, 2001.

[11] D. Hunt, "Farm Power and Machinery Management", Ames, Iowa: Iowa State University Press, Ames, Iowa, USA, 1995.

[12] D. Kehayov, C. Vezirov, and A. Atanasov, "Some technical aspects of cut height in wheat harvest", Agronomy Research, vol. 2, pp. 181-186, 2004.

[13] D. R. Buckmaster, "Benchmarking tractor costs; a technical note", Applied Engineering in Agriculture, vol. 19, pp. 151-154, 2003.

[14] F. Henrichsmeyer, J. Ohls, and K. Winter, "Leistung und Kosten von Arbeitsverfahren in Grossbetrieben (Work requirement and costs on large farms)", Landtechnik, vol. 50, pp. 296-297, 1995.

[15] H. Sharanakumar, R. U. Udhaykumar, and K. T. Ramappa, "Technoeconomic feasibility of rice combine harvester", Journal of Engineering and Technology in India, vol. 2, pp. 13-17, 2011.

[16] J. Masek, P. Novak, and T. Pavlicek, "Evaluation of combine harvester fuel consumption and operation cost", Engineering for Rural Development, Jelgava, vol. 5, pp. 78-83, 2015.

[17] J. Soucek, and D. Blazej, "Linseed harvests parameters depending on the state of cutting mechanism", Research in Agricultural Engineering, vol. 58, pp. 46-49, 2012

[18] L. A. Yousif, and S. E. A. E. Awad, "Performance evaluation of combine harvester and the P.T.O. tractor operated thresher for stationary threshing of sorghum", Agricultural Mechanization in Asia, Africa and Latin America, vol. 43, pp. 52-56, 2012.

[19] L. Spokas, and D. Steponavicius, "Fuel consumption during cereal and rape harvesting and methods of its reduction", Journal of Food, Agriculture and Environment, vol. 9, pp. 257-263, 2011.

[20] L. Spokas, V. Adamcuk, V. Bulgakov, and L. Nozdrovicky, "The experimental research of combine harvesters", Research in Agricultural Engineering, vol. 62, pp. 106-112, 2016.

[21] L. William, "Farm Machinery Economic Cost Estimates", Extension Farm Management Specialist, Nebraska University, USA, 2005.

[22] M. A. Hossain, M. A. Hoque, M. A. Wohab, M. A. Miah, and M. S. Hassan, "Technical and economic performance of combine harvester in farmers' field", Bangladesh Journal of Agricultural Research, vol. 40, pp. 291-304, 2015.

[23] M. A. S. Mandal, M. J. Kabir, M. S. Kabir, M. A. Salam, M. A. Islam, M. I. Omar, M. A. R. Sarkar, M. C. Rahman, A. Chowdhury, M. S. Rahaman, L. Deb, M. A. Aziz, and M. A. B. Siddique, "Harvesting of Boro Paddy in Haor Areas of Bangladesh: Interplay of Local and Migrant Labour, Mechanized Harvesters and Covid-19 Vigilance in 2020", 40 pages, BRRI, Gazipur, Bangladesh, 2020. Available online: https://www.researchgate.net/publication/342530055_Harvesting_of_ Boro_Paddy_in_Haor_Areas_of_Bangladesh_Interplay_of_Local_an 
d_Migrant_Labour_Mechanized_Harvesters_and_Covid-

19_Vigilance_in_2020.

[24] M. G. K. Bhuiyan, A. K. M. S. Islam, M. Kamruzzaman, M. A. Alam, H. Paul, and M. M. Islam, "Opportunity of local service provider on custom hiring business of combine harvester for small holder farmers' in haor areas", Journal of Agricultural Engineering, Institute of Engineers, Bangladesh, vol. 43, pp. 85-94, 2020.

[25] M. K. Hasan, M. R. Ali, C. K. Saha, M. M. Alam, and M. M. Hossain, "Assessment of paddy harvesting practices of Southern Delta Region in Bangladesh", Progressive Agriculture, vol. 30, pp. 57-64, 2019.

[26] M. Kavka, M. Mimra, and F. Kumhala, "Sensitivity analysis of key operating parameters of combine harvesters", Research in Agricultural Engineering, vol. 62, pp. 113-121, 2016.

[27] M. R. Alizadeh, and A. Allameh, "2013. Evaluating rice losses in various harvesting practices", Int Res J Appl Basic Sci, vol. 4, pp. 894901, 2013.

[28] N. E. Isaac, G. R. Quick, S. J. Birrell, W. M. Edwards, and B. A. Coers, "Combine harvester economic model with forward speed optimization", Applied Engineering in Agriculture, vol. 22, pp. 25- 31, 2006.

[29] R. A. Kepner, R. Bainer, and E. L. Barger, "Principles of Farm Machinery", 3rd edition, AVI Publishing Company, Inc, West Port Connecticut, USA, 1982.

[30] Sazzad, "Field performance of DAEDONG combine harvester", $M S$ thesis, Department of Farm Power and Machinery, Bangladesh Agricultural University, Mymensingh, Bangladesh, 2014.

[31] S. K. Amponsah, A. Addo, K. A. Dzisi, J. Moreira, and S. A. Ndindeng, "Performance evaluation and field characterization of the sifang mini rice combine harvester", Applied Engineering in Agriculture, vol. 33, pp. 479-489, 2017.

[32] V. Tymchuk, V. Kirichenko, and V. Petrenkova, "Impact of Agricultural Transition on Soil Protection in Ukraine: The Role of Institutional Change. Bondarenko E. Recommendations for harvesting early cereals and legumes", Agronomy Today, Available online: http://agrobusiness.com.ua/agro/ahronomiia-sohodni/item/ 582rekomendatsii-do-zbyrannia-rannikhzernovykh-tazernobobovykh.html. 2015.

AKM Saiful Islam is Principal Scientific Officer in the Farm Machinery and Post-Harvest Technology Division, Bangladesh Rice Research Institute, Gazipur, Bangladesh. He achieved his PhD from Farm Power and Machinery, Bangladesh Agricultural University, Bangladesh.

Md. Ashraful Alam is Senior Scientific Officer in the Farm Machinery and Post-Harvest Technology Division, Bangladesh Rice Research Institute, Gazipur, Bangladesh. He achieved his PhD from Farm Power and Machinery, Bangladesh Agricultural University, Bangladesh.

M. Kamruzzaman is Senior Scientific Officer in the Farm Machinery and Post-Harvest Technology Division, Bangladesh Rice Research Institute, Gazipur, Bangladesh. He achieved his PhD in Engineering from Gyeongsang National University, South Korea.

Md. Golam Kibria Bhuiyan is Senior Scientific Officer in the Farm Machinery and Post-Harvest Technology Division, Bangladesh Rice Research Institute, Gazipur, Bangladesh. He achieved his PhD from Farm Power and Machinery, Bangladesh Agricultural University, Bangladesh.

Md. Monirul Islam is Scientific Officer in the Farm Machinery and PostHarvest Technology Division, Bangladesh Rice Research Institute, Gazipur, Bangladesh. He earned his Master's Degree from Farm Power and Machinery, Bangladesh Agricultural University, Bangladesh.

Mohammad Rezoan Bin Hafiz Pranto is Scientific Officer in the Irrigation and Water Management Division, Bangladesh Rice Research Institute, Gazipur, Bangladesh. He completed his Master's Degree from Farm Structure, Bangladesh Agricultural University, Bangladesh. 